Bangladesh J. Bot. 37(1): 49-53, 2008 (June)

\title{
DISTRIBUTION OF BLUE-GREEN ALGAE IN SOILS OF CHITTAGONG UNIVERSITY CAMPUS AND THEIR NITROGEN FIXING CAPACITY
}

\author{
M.A. Gafur and Soltana Parvin \\ Department of Botany, University of Chittagong, Chittagong-4331, Bangladesh
}

Key words: BGA, Distribution, Nitrogen fixation

\begin{abstract}
Occurrence of blue-green algae in plain land, pond side, hilly area and dry rice field soils of Chittagong University Campus and $\mathrm{N}_{2}$ fixation of some of them have been studied. Twenty four species under 20 genera were identified and their number varied from $0.11 \times 10^{4} / \mathrm{g}$ to $2.8 \times 10^{4} / \mathrm{g}$ soil. Anabaena oryzae, Calothrix sp., Cylindrospermum majus and Hapalosiphon hibernicus and Nostoc spongiaeforme were selected for their nitrogen fixing potential. Maximum amount of total nitrogen was recorded in Nostoc spongiaeforme followed by Hapalosiphon hibernicus, Cylindrospermum majus, Anabaena oryzae and Calothrix sp. after 30 days growth in batch cultures.
\end{abstract}

\section{Introduction}

Members of the division Cyanophyta/Cyanobacteria are perhaps of greater ecological importance as pioneer forms than the members of any other class of algae. Some information are available on the distribution and nitrogen fixing capacity of cyanobacteria in the rice fields of Bangladesh (Aziz et al. 1992, Begum 1983, Begum and Mandal 1997, Begum et al. 1993, Bhuiya et al. 1981, Khan and Venkataraman 1991, Mandal et al. 1993). There is also a good number of systematic studies on the blue-green algae (BGA) from different habitats (Aziz and Yasmin 1997, Gafur and Uddin 1992, Islam 1973b, Islam and Aziz 1979, Islam and Uddin 1969, 1973, 1978a, b) but only a few information exists (Aziz et al. 1992, Begum et al. 1993) about the occurrence and their distribution of the soil BGA of Bangladesh.

It was estimated that in the Philippino rice fields BGA adds up to $40 \mathrm{~kg}$ nitrogen per hectare per year to the soil (Watanabe et al. 1977). Rother et al. (1988) estimated nitrogen fixation inside deepwater rice fields 16.7 and $8.2 \mathrm{~kg}$ nitrogen per hectare per flood season at Manikganj and Sonargaon, Bangladesh, respectively. De (1939) demonstrated that the fertility of tropical rice field soil is maintained by the blue-green algae through dinitrogen fixation. Thus it was important to examine the occurrence, distribution and quantitative enumeration and isolation of blue-green algae and to study nitrogen fixing potential of some isolates.

\section{Materials and Methods}

The Chittagong University Campus lies in the longitude of about $91^{\circ} 5^{\prime}$ east and latitude of $22^{\circ} 30^{\prime}$ north and covers a total area of 520 hectares which is mostly hilly (Gafur et al. 1979).

Thirty soil samples were collected at 0 to $15 \mathrm{~cm}$ depth from plain land, pond side, hilly area, dry rice fields and each was composite of five sub-samples. Two grams of each of the air dried soil sample were transferred into the conical flask containing sterilized Chu-10D medium (Chu 1942) and incubated. After 21 days a mixed growth of BGA was observed. These were microscopically examined and identified. The quantitative enumeration of BGA in the samples was done by most probable number method with the help of MPN chart from the number of positive tubes inoculated with higher dilutions (Alexander 1965).

From the mixed algal growth BGA were isolated and cultured in nitrogen free liquid medium under natural light and room temperature. The algal mass for each isolate after growth for 30 days 
was separated from the medium by filtration through Whatman No. 41 paper and nitrogen content was determined by microkjeldahl digestion and distillation method (Jackson 1958).

\section{Results and Discussion}

The number of BGA/g soil obtained after 21 days growth in conical flasks in shown is Table 1. Maximum number was obtained in soils of slopes of a pond, south of Botanical Gardens. This was followed by plain land in front of RCMPS, mid-hill regions low land rice fields, etc.

Cyanobacterial number varied from $0.11 \times 10^{4} / \mathrm{g}$ to $2.80 \times 10^{4} / \mathrm{g}$ soil (Table 1 ). The number of nitrogen fixers in soil samples of four places in the study areas was higher in the present study compared to that reported by Mandal et al. (1993).

Table 1. Number of blue-green algae in different soil samples of Chittagong University Campus.

\begin{tabular}{|c|c|c|c|}
\hline $\begin{array}{c}\text { Sample } \\
\text { no. }\end{array}$ & Description of sites & $\begin{array}{l}\text { No. of BGA/g } \\
\text { soil }\left(\times 10^{4}\right)\end{array}$ & $\begin{array}{l}95 \% \text { confidence } \\
\text { limit }\left(\times 10^{4}\right)\end{array}$ \\
\hline 1. & Lemon corner, Botanic Garden, plain land & 1.40 & $0.42-4.62$ \\
\hline 2. & Jack fruit corner, Botanic Garden, plain land & 0.70 & $0.21-2.31$ \\
\hline 3. & Near Orchid house, Botanic Garden, plain land & 1.10 & $0.33-3.63$ \\
\hline 4. & Miscellaneous corner, Botanic Garden, plain land & 0.17 & $0.05-0.56$ \\
\hline 5. & Slope of a pond, south of Botanic Garden & 2.80 & $0.84-9.24$ \\
\hline 6. & Rice field, beside Botanic Garden & 0.70 & $0.21-2.31$ \\
\hline 7. & Side of a stream, east of Botanic Garden & 0.79 & $0.23-2.60$ \\
\hline 8. & Foot hill, east of Botanic Garden & 0.33 & $0.10-1.08$ \\
\hline 9. & Low land rice field, south-east of Botanic Garden & 0.11 & $0.03-0.36$ \\
\hline 10. & $\begin{array}{l}\text { Plain land, infront of Research Centre for } \\
\text { Mathematical and Physical Sciences (RCMPS) }\end{array}$ & 2.20 & $0.66-7.26$ \\
\hline 11. & Bank of a pond near RCMPS & 0.70 & $0.21-2.31$ \\
\hline 12. & Plain land, west of RCMPS & 1.10 & $0.33-3.63$ \\
\hline 13. & Low land rice field, west of RCMPS & 1.70 & $0.51-5.61$ \\
\hline 14. & Low land rice field, north of RCMPS & 0.79 & $0.23-2.60$ \\
\hline 15. & Hill top, south of Pritilata Hall & 0.49 & $0.14-1.61$ \\
\hline 16. & Mid-hill region, south of Pritilata Hall & 2.20 & $0.66-7.26$ \\
\hline 17. & Low land rice field, east of V. C. hill & 1.10 & $0.33-3.63$ \\
\hline 18. & Plain land, north of Shamsun Nahar Hall & 0.22 & $0.06-0.73$ \\
\hline 19. & Low land rice field, north of Shamsun Nahar Hall & 1.40 & $0.42-4.62$ \\
\hline 20. & Mid-hill region, east of Shamsun Nahar Hall & 1.40 & $0.42-4.62$ \\
\hline 21. & Foot-hill, east of Shamsun Nahar Hall & 0.79 & $0.23-2.60$ \\
\hline 22. & Foot-hill, west side of Shahid Minar & 1.40 & $0.42-4.62$ \\
\hline 23. & Mid-hill region, west of Shahid Minar & 0.17 & $0.05-0.56$ \\
\hline 24. & Foot-hill, west of Central library & 0.49 & $0.14-1.61$ \\
\hline 25. & Low land rice field, west of Shahid Minar & 0.49 & $0.14-1.61$ \\
\hline 26. & Low land rice field, south-east of Science Faculty & 1.30 & $0.39-4.29$ \\
\hline 27. & Foot-hill, south of Science Faculty & 0.17 & $0.05-0.56$ \\
\hline 28. & Mid-hill region, south of Science Faculty & 0.14 & $0.04-0.46$ \\
\hline 29. & Low land rice field, south of Science work shop & 0.70 & $0.21-2.31$ \\
\hline 30. & Low land rice field, north of IMS & 1.10 & $0.33-3.63$ \\
\hline
\end{tabular}


Twenty four species under 20 genera of BGA were identified from different sites (Table 2). Among these species, six belong to family Chrococcaceae, five to Oscillatoriaceae, seven to Nostocaceae, one from Rivulariaceae, one from Scytonemataceae and four from Stigonemataceae.

A highest percentage of occurrence $(76.67 \%)$ was observed by various species of Nostoc followed by Anabaena oryzae (66.67\%) and the lowest was for Aphanothece microscopica, Oscillatoria princeps and Stigonema sp. (10\%). Aulosira sp., M. flos-aquae and Spirulina gigantea were found rarely (Table 2). Nostoc spongiaeforme alone occupied 3rd position in terms of $\%$ occurrence.

Table 2. Percentage occurrence of blue-green algae in soils of Chittagong University Campus.

\begin{tabular}{lc}
\hline Name of the species & Percentage of occurrence* \\
\hline Nostoc sp. & 76.67 \\
Anabaena oryzae & 66.67 \\
Nostoc spongiaeforme & 60.00 \\
Lyngbya sp. & 46.67 \\
Chroococcus sp. & 40.00 \\
Fischerella muscicola & 40.00 \\
Gloeocapsa sp. & 40.00 \\
Anabaena iyengarii & 36.67 \\
Pseudanabaena sp. & 33.33 \\
Phormidium sp. & 33.33 \\
Cylindrospermum majus & 30.00 \\
Hapalosiphon hibernicus & 26.67 \\
Calothrix sp. & 26.67 \\
Westiellopsis prolifica & 23.33 \\
Synecococcus sp. & 23.33 \\
Scytonema sp. & 23.33 \\
Spirulina gigantea & 23.33 \\
Aulosira sp. & 20.00 \\
Microcystis marginata & 16.67 \\
Oscillatoria sp. & 13.33 \\
Microcytis flos-aquae & 13.33 \\
Aphanothece microscopica & 10.00 \\
Oscillatoria princeps & 10.00 \\
Stigonema sp. & 10.00 \\
\hline
\end{tabular}

*Calculated from the presence of a species in number of samples out of total 30 samples.

It appears that spp. of Nostoc, A. oryzae and $N$. spongiaeforme are the most widely distributed algae in the sampling areas (Table 2). The result corroborates with the reports of Begum et al. (1993), Islam and Aziz (1979), Islam and Uddin (1978a, b), Bhuiya et al. (1981), Khan and Venkataraman (1991). Hapalosiphon hibernicus reported in the soils of Bangladesh (Begum et al. 1993, Islam and Uddin 1978b, Khan and Venkataraman 1991) was also present in the study area. Fischerella sp. is one of the most common soils nitrogen fixing blue-green algae (Begum et al. 1993) and was also present in the study areas.

The amount of nitrogen fixed increased with the age of culture in N. spongiaeforme, A. oryzae, C. majus and H. hibernicus but it decreased in case of Calothrix sp. (Table 3). The highest amount of nitrogen content was found in $N$. spongiaeforme $(3.38 \mathrm{mg} / \mathrm{g}$ biomass $/ 30$ days) followed by $H$. hibernicus $(2.90 \mathrm{mg} / \mathrm{g}$ biomass $/ 30$ days) and the lowest was found in Calothrix sp. (1.45 $\mathrm{mg} / \mathrm{g}$ biomass $/ 30$ days). The amount of nitrogen content by A. oryzae was $1.86 \mathrm{mg} / \mathrm{g}$ biomass $/ 30$ days. In the present investigation $N$. spongiaeforme showed maximum $\mathrm{N}_{2}$-fixation after 30 days incubation. 
Table 3. Nitrogen fixation by some isolates of cyanobacteria.

\begin{tabular}{lccccc}
\hline \multirow{2}{*}{ Algal isolates } & \multicolumn{5}{c}{$\begin{array}{c}\text { Nitrogen content (mg/g dry wt.) of different isolates in different } \\
\text { incubation periods (days) }\end{array}$} \\
\cline { 2 - 6 } & 15 & 20 & 25 & 28 & 30 \\
\hline Nostoc spongiaeforme & 1.20 & 2.25 & 3.09 & 3.28 & 3.38 \\
Anabaena oryzae & 1.13 & 1.50 & 1.50 & 1.61 & 1.86 \\
Calothrix sp. & 0.41 & 0.97 & 1.61 & 1.54 & 1.45 \\
Cylindrospermum majus & 0.16 & 0.69 & 0.81 & 1.52 & 2.45 \\
Hapalosiphon hibernicus & 0.97 & 1.29 & 1.35 & 1.79 & 2.90 \\
\hline
\end{tabular}

Highest amount of total nitrogen content was observed in Nostoc commune $\left(5.41 \mathrm{mg}^{2} \mathrm{ml}^{-1}\right.$ 30 days) from the soils of Jhenaidah, Bangladesh (Begum and Mandal 1997). Low amount of $\mathrm{N}_{2}$ fixation by Calothrix wembaerensis was reported by Begum and Mandal (1997) which corroborates with the present findings. In the present study $\mathrm{H}$. hibernicus showed much more $\mathrm{N}_{2}$ fixation at 30 days incubation than that reported by Begum and Mandal (1997).

\section{Acknowledgement}

The authors are grateful to Professor Dr. K.T. Osman, Department of Soil Science, University of Chittagong for his help in the preparation of the manuscript.

\section{References}

Alexander, M. 1965. Most Probable Number Method for Microbial Population. In: Methods of Soil Analysis. Part II (C.A. Black ed), pp. 1467-1472. Amer. Soc. Agron. Moddison.

Aziz, A. and N. Yasmin. 1997. Algal flora of Madhabkunda waterfall area in Moulvibazar, Bangladesh. I. Blue-green and red algae. Bangladesh J. Bot. 26(1): 9-18.

Aziz, A., G.L. Gaine and M. Khatun. 1992. Systematics and ecology of rice-field soil algae of Bangladesh. In: Plant Science and Man: Problems and Prospects (A.K.M.N. Islam, Q.A. Fattah, I.A. Muttaqui and A. Aziz. Eds.), pp. 23-34. Proc. Intl. Bot. Conf., 10-12 January, 1991, Bangladesh Bot. Soc., Dhaka, Bangladesh.

Begum, Z.N.T. 1983. Cultural studies of some nitrogen fixing blue-green algae from rice field. Bangladesh J. Bot. 12(2): 127-131.

Begum, Z.N.T. and R. Mandal. 1997. Nitrogen fixing capacity of some cyanobacterial strains from Bangladseh. J. Phytol. Res. 10(1): 67-73.

Begum, Z.N.T., Z.U.M. Khan, R. Mandal and M.Z. Hossain. 1993. Distributional pattern of nitrogen-fixing cyanobacteria in rice fields of Bangladesh. Phykos. 32(1\&2): 109-114.

Bhuiya, Z.H., M.A. Hashem and A.K.M.N. Islam. 1981. Isolation and identification of dominant nitrogenfixing blue-green algae from Bangladesh soils. In: Current perspective in nitrogen-fixation (A.H. Gibson and W. E. Newton, Eds.), pp. 498. Elsevior/North-Holland Biomedical press, Amsterdam.

Chu, S.P. 1942. The influence of the mineral composition of the medium on the growth of planktonic algae. 1. Methods and culture media. J. Ecol. 30: 284-325.

De, P.K. 1939. The role of blue-green in nitrogen fixation in rice-fields. Proc. Roy. Soc. London. 127: 121139.

Gafur, M.A. and M. Uddin. 1992. Algal flora of Chittagong University Campus. II. Cyanophyceae. Chittagong Univ. Stud. Part II 16(2). 27-34.

Gafur, M.A., A. Karim and M.A.A. Khan. 1979. Phytosociological studies of the hills of the Chittagong University Campus. Chittagong Univ. Stud. Part II 3:11-28.

Islam. A.K.M.N. 1973b. Fresh water algae of Bangladesh. Dacca Univ. Stud. Pt. B. 21(2): 133-139. 
Islam. A.K.M.N. and A. Aziz. 1979. Algal flora of Moheshkhali Island, Bangladesh. Dacca Univ. Stud. Pt. B. 27(2): 105-122.

Islam. A.K.M.N. and A. Uddin. 1969. Studies on the blue green algae of Dacca District. Dacca Univ. Stud. Pt. B 17: 85-102.

Islam. A.K.M.N. and A. Uddin. 1973. Fresh water algae of Bangladesh. II. Cyanophyceae. Dacca Univ. Stud. Pt. B 21(2):127-132.

Islam. A.K.M.N. and A. Uddin. 1978a. Blue green algae from Dacca, Bangladesh. II. Oscillatoriaceae. Dacca Univ. Stud. Pt. B 26(1): 73-84.

Islam. A.K.M.N. and A. Uddin. 1978b. Blue green algae from Dacca, Bangladesh. III. Nostocaceae, Scytonemataceae and Stigonemataceae. Dacca Univ. Stud. Pt. B 26(1): 85-93.

Jackson, M.I. 1973. Soil chemical analysis. Prentice-Hall, Inc. Engle Wood Cliffs, N.J.U.S.A . pp. 183-203.

Khan, Z.U.M. and G.S. Venkataraman. 1991. Distribution of nitrogen fixing blue-green algae in rice soils of Bangladesh. J. Nature Stud. 1: 31-36.

Mandal, R., Z.N.T. Begum, Zahed. U.M. Khan and M.Z. Hossain. 1993. $\mathrm{N}_{2}$-fixing blue-green algae in rice fields and their relationship with soil fertility. Bangladesh J. Bot. 22(1): 71-79.

Rother, J.A., Abdul Aziz, N. Hye Karim and B.A. Whitton. 1988. Ecology of deepwater rice fields in Bangladesh. 4. Nitrogen fixation by blue green algal communities. Hydrobiologia. 169: 43-56.

Watanabe, I., A.K.K. Leed, B.V. Alimagno, M. Sato, D.C. del Rosario, M.R. de Gujman. 1977. Biological nitrogen-fixation in paddy fields studied by in situ acetylene-reduction assays. IRRI Research paper series. 4: 43-54.

(Manuscript received on 24 March, 2008; revised on 5 May, 2008) 